\title{
Staging The North-South Meridian: SPATIAL AND ONTOLOGical EXPlorations OF THE Northern EXPERIENCE IN Two CaNadian Dramas
}

\begin{abstract}
Wendy Lill's 1986 monodrama The Occupation of Heather Rose employs the image of nurse and nursing, generally rich in positive associations, to make an unquestionably political statement about "whites in the wrong places," and about the imposition of the mainstream society's health care rhetoric upon the culturally distant and gravely maltreated northern communities in Canada. The play reveals not only the failure of the federal scheme as inappropriate and culturally insensitive, but also exposes its operation as one of the means of maintaining and structuring the persistent colonial legacy of which the character of the play, as well as the mainstream society, is both witness and victim.

Minnie Aodla Freeman's earlier, 1971 play Survival in the South offers a directionally opposed perspective on the Northern experience: the first drama ever written by an Inuk is an authentic attempt to come to aesthetic, as well as emotional terms with the experience of the author's journey of (self)discovery of the Canadian south, and to contribute to establishing an independent contemporary Inuit literary culture which would help defend the ethnic and cultural standing of the Northern people.

The article analyzes and compares the two women authors' dramatic journeys to/from the North in the larger context of the discourse of the North in Canada, with the aim to represent the Canadian North as experienced by the country's people on both sides of the geographical and cultural, perhaps self-constructed divide.
\end{abstract}

\section{Key words}

Canadian drama; contemporary theatre; Inuit culture; women playwrights; discourse of the North 
Since the beginning of the explicit formation of its national identity and selfconsciousness in the $19^{\text {th }}$ century, Canada has typically identified itself with the North, and created for itself a specific "northern" discursive conception which has served many of the country's ideological, ontological, as well as practical and political needs. In 1869 Robert Grant Haliburton was among the first thinkers who explicitly articulated the northernness of Canada in not only geographical, but also political and cultural terms - in his lecture titled "The Men of the North and Their Place in History" he argued that the North was not only Canada's inescapable spatial positioning, but also the richest source of its wealth, national pride, and future stability. His belief is reflected a century later in Prime Minister Diefenbaker's program titled "Northern Vision," as well as in the development of Canadian popular imaginary. Sherrill Grace, a chief authority on the northern discourse among Canadian scholars, describes:

Whether as a "friendly" place of potential resource wealth and a place for dangerous adventure or as a barren land empty of little but snow, ice, wolves, and the threat of starvation and death, Canada has come to be equated with the North. What the explorers, traders, geographers, historians, and politicians constructed in economic, cartographic, historiographic, and political terms, our artists have trained us to see, feel, and recognize as a Canadian identity. We have been - and continue to be - constructed and represented as "the men of the North," whose "place in the history"... is to guard "the true North strong and free," with a Northern Magus" for a prime minister and a wine labeled "49 North." (Grace 2001: 124)

Considering such an undeniable centrality of the North in the history of Canadian culture, it is hardly surprising that its presence has been reflected in all the dominant formats of artistic expression, including drama and theatre. One of the first anthologies of Canadian drama, edited by Herman Voaden and published in 1930 under the simple title Six Canadian Plays, was consciously dedicated "to the North," and in the introduction to it Voaden formulated his intent to find in the North not only authentic Canadian setting and subject matter, but also original style and form for his project of emergent national theatre. For Voaden, the connection between the North, the nationalistic agenda of the day and the creation of original discourse for the arts in Canada was unquestionable:

He wanted to foster a Canadian theatre, and he believed passionately that such a theatre would spring from a desire to dramatize "the north." He did not ask what "the north" meant or where it might be located. Voaden's North was the country stretching north of Lake Superior, the country painted by the Group of Seven; it was up and out there; it was ultimately, for Voaden, synonymous with Canada. In Voaden's mind a Canadian theatre would naturally be northern, whether it took a realist form to explore human relations and social issues, a romantic form to explore historical subjects or heroic 
struggles, or a variety of more experimental forms that might, as in his own plays, exploit the connections between drama, music and the visual arts... As Voaden knew, plays about the North are not limited by a northern landscape but embedded in it. (Grace 2001: 141)

In spite of the scepticism of some historians of theatre concerning the applicability of the North for theatrical representation - expressed, for example, in Brian Parker's 1977 essay "Is There a Canadian Drama?," in which the author admitted the significance of the North as one of the essential components of Canadian national mythology, but at the same time formulated his belief that the myth of the North was "antidramatic" - the amount, as well as the quality of Canadian northern plays appears to substantiate Sherrill Grace's assertion that: "The stage is no stranger to northern discourse. Indeed, the theatre has proved to be one of the most contentious places for articulating and presenting ideas of North" (Grace 2001: 140).

However, the overwhelming majority of Canadian northern plays that have been published and produced by theatres, and thus have had a chance to reach the awareness of Canadians, have been written by southerners, and thus present a perspective of unmistakable cultural and aesthetic difference. This creates a situation in which understanding is problematized, and genuine representation faces a number of ontological, as well as discursive limitations. "Because these plays are presented to southern, urban audiences, often on main stages of major theatres, they represent a North that mirrors southern ideas of North, that dramatizes social, psychological, and ethical problems that concern southerners, and that sees the North in terms of the South" (Grace 2001: 141-142). Sherrill Grace further elaborates on the outcomes of the presence of such a perspective, from which the North is:

... viewed as a place of spiritual beauty, silence, even transcendence, and of terror - a place of isolation, madness, and death. To the southern mind, the North is a paradox: it is at once empty / with nothing but lakes, rivers, forests, muskeg, taiga, tundra, and ice - and full - full of exotic peoples, caribou, mineral riches, unsolved mysteries, and ghosts. (Grace ed., 1999: xi)

In some of these dramas, the North is thus not merely a luring site of masculine adventure, or a sinister image of "hell frozen over," but, rather, a symbol of Canada's relationship to its "Other," in many senses of the word, and an implement for voicing certain deeply rooted private, as well as cultural anxieties and deficiencies. One of the most powerful of such plays is Wendy Lill's 1986 monodrama The Occupation of Heather Rose.

In one of the reviews of the play the story it tells is described as follows:

It can't possibly be that difficult to fix all the problems afflicting a northern Canadian Reserve. At least, that is what Heather Rose thinks. After becoming a nurse, she travels to a remote reserve in northern Ontario with a copy 
of the Canada Food Guide and a can-do attitude, expecting that everything will work out fine. It doesn’t. (Wyonarski: 2011)

The play, labeled also as a "confessional monologue," is inspired by the author's own experience of working as a consultant with the Canadian Mental Health Association in the late 1970s, and being based in the remote, hostile, and underprivileged Canadian North. Its solo character, Heather Rose, is a once idealistic nurse thinking of herself as a modern Florence Nightingale with "a fresh new outlook" (Grace, ed., 1999: 307), who reports to the audience about the experience of her placement on the Native Canadian reserve, of the grand failure of her well-meant mission, and of her consequent ominous mental disintegration.

At first sight, Heather seems (or, rather, assumes) to be well prepared for her mission, which purports to serve the best of intentions: she is young, enthusiastic, genuinely honest, seemingly devoted to her job and her patients, and willing to meet the challenge of her choice. In the beginning of the play, she recollects her first impressions of her new posting in the North as follows:

The nursing station. It had such a nice ring to it, I thought. The nursing station. Where the nurse was stationed. Where she was present and waiting for people in distress. In need of help. The first thing I did was unpack Mother and Grandmother. I mean their pictures! I set them up on the arborite desk with their nursing caps and serene smiles to guide me in my work at Snake Lake. (Grace, ed., 1999: 302)

On the surface of things, Heather, who, with growing irony, refers to herself as "the resident Florence Nightingale" (Grace, ed., 1999: 315), corresponds with this generally accepted icon of the best essence of her profession. After all, "the notion of doing good, being good, and acting on the good, which resembles virtue ethics, was addressed by Florence Nightingale [herself] when she said that it was impossible to be a good nurse without being a good woman" (Sartorio and Zoboli 2010: 687). Soon, however, Heather's enthusiasm and goodwill prove to be no more than a set of culturally formatted assumptions about one's, and one's own culture's superiority and self-righteousness, of which the title of the play serves as a particularly potent metaphor, which "reminds us that [Heather's] work as a northern nurse is an imposition of colonial priorities on northern peoples, that she is, in fact, occupying foreign territory, stolen land" (Anderson et. al. 1997: 88). The process begins by Heather's measuring of these assumptions against incontestable aspects of reality that cannot escape her:

At orientation, Miss Jackson told us Indians don't look you in the eye. And it's true. She was at least right about that. Camilla Loon looked at the top button of my uniform as if it had some mysterious power over her. And Mary $\mathrm{K}$. looked at my feet when I tried to shake hands with her. But that didn't bother me "cause it gave me a chance to study them. (Grace, ed., 1999: 305) 
Heather's approach to this "study" is based on the simple "compare and contrast" method, and soon proves its limitations; about her meeting with the chief, for example, she recollects that:

[he] told me it was getting harder and harder to eat well and stay healthy at Snake Lake. That the fish were full of chemicals from the paper plant up the river, that the wild rice didn't grow since the government put in the hydro dam. And that it was hard to keep your kids clean when there wasn't enough money for proper sewage. And that...

HEATHER holds up her hand to interrupt.

"Hey! Excuse me, Chief! But I know all about the problems. I learned it all at orientation week. I want to talk about solutions. I've been thinking about an exercise club for women to improve their self-image... women always need to improve their self-image. And a good food club to work on our eating habits now that fish and wild rice have been kind of blown out of the water. Ha ha." (Grace, ed., 1999: 306)

The extract epitomizes, in an open and uncompromising manner, the unflattering social reality of the North, including, perhaps surprisingly, the alarming issue of environmental damage, and identifies the cause of the problems in the outsider's attitude, radiating superiority, lack of empathy, and inappropriateness. As the central vehicle of this attitude the play employs the image of nurse and nursing, generally rich in positive associations, to make an unquestionably political statement about "whites in the wrong places," and about the imposition of the mainstream society's health care rhetoric upon the culturally distant and gravely maltreated minority communities in Canada. What makes her realization of this particularly arduous for Heather, the audience's only informant, is not only her personal intellectual inadequacy - she honestly admits to being "no Einstein!" (Grace, ed., 1999: 307) - but it is also her understandable, if not legitimate inability to make an accurate judgment of the cultural specificity of her training and the methodology of her profession. The play thus illustratively:

... dramatizes many of the familiar elements in the story of southern Canadian attitudes about the North and the delivery of health care to northern communities. However, Lill is not interested in merely recapitulating a familiar narrative, let alone in reinforcing a sentimental, self-serving, colonialist one... The playwright turns the gaze of the southerner inward in a play that analyses southern illusions about the North and the destructive assumptions that fuel these illusions. (Anderson et al. 1997: 85)

These illusions are many, and firmly set; however, when faced with reality, they crumble in Heather's mind at a speed which astonishes her to the point that she qualifies them as "bullshit" (Grace, ed., 1999: 312), and admits her discouragement, disillusionment and alienation - not only from her placement and mission, 
but, more importantly, from the inner substance of her professional identity and belonging. It takes a lot from Heather to confess to the audience, and thus to make the first step to potential self-recognition, that: "I felt embarrassed about my silly fantasies. That's all they were. Fantasies. There was no connection between the Romance of the North and my tired lonely existence as a Northern Nurse. I'd been tricked somehow" (Grace, ed., 1999: 316).

It seems that Heather has been tricked by the common fallacy of her profession: that as a nurse, thus by definition as a provider of medical assistance, support and perhaps hope, she cannot possibly make the mistake of wrongly assessing her patients' needs, and of differential treatment of them. Lill hereby points out to a larger problem, identified likewise by medical research: nurses, trained to know and deal with human bodies as essentially identical, often refuse, whether consciously or not, to admit to racial differentiation and ensuing racial prejudice, with which they may be affected themselves:

Maybe it is because nurses, who know facts of human physical uniformity, who know that disease knows no colour line and who have pledged themselves to relieve suffering humanity regardless of race, creed or colour, cannot in all consciousness condone any form of discrimination. (Carnegie and Osborne 1985: 148)

Heather, struggling non-comprehendingly with the indifference of, and rejection by her patients, who have been let down by the system so many times before her arrival, confirms by her attitude the extant paradigm: "The contradictions between caring, a principle part of the identity of nursing, and racism make it difficult for nurses to acknowledge racial prejudice in the profession." (Barbee 1993: 346)

The most profoundly ironic moment in Heather's confession, which serves as the dramatic culmination of her monologue, comes when she feels tricked by the system that "occupies" her, begins to see its bias, ineffectuality, and even corruption, but considers herself, its servant and representative, to be its victim, while ignoring that the real injustice is being committed by that same system against her helpless, downtrodden, and sulking patients. When she reports to the audience about the inspection visit to the reservation from a white administrator from the South (with whom she vainly tried to flirt at the time, thus betraying another of her deeply anchored frustrations, which she later lets out at her patients), her "optimistic, cheery" (Grace, ed., 1999: 299) rhetoric undergoes its first, dramatic change:

All those fucking high-paid whites coming through to help the Indians - not little me! Flying in and out, in and out, consulting on this, consulting on that, flashing their million dollar smiles, stalking about the reserve from plane to community hall, to band office, to plane, with their Indian friends, being helpful and advisory, then back in the air... There was no help for me, 
except my rum toddies. Want another one? Don't mind if I do. (Grace, ed., 1999: 321)

With nearly absurd irony, Heather reveals at this moment yet another striking, because convincing, and certainly functional paradox of her situation: it is the Native people that are supposed to be prone to alcoholism, that being one of the most easily identifiable "Indian problems"; still, on Heather reservation, it is only her and her fellow "resident whites" that resort to the bottle, to drown their reluctantly conceded sense of failure, insecurity, and alienation. Here Heather betrays not only her professional responsibility, but also her ultimate personal role model and authority - the example of Florence Nightingale herself, the quintessence of a "good nurse":

Nightingale fought against environments in which nurses were poorly regarded or worked in unhealthy conditions in ignorance of basic hygiene. The virtues defended by Nightingale must be seen as weapons with which to fight practices such as not following medical orders, being deceitful, taking bribes, and drunkenness. Because of this, she accorded the highest importance to the virtues of truthfulness, sobriety and honesty. The behavior of immoral nurses needed to be abolished if respectable ladies were to be recruited to care for sick people. Only then could nursing be a suitable employment for educated women guided by science and morality. (Sartorio and Zoboli 2010: 688)

The factual and emotional curve of Heather's defeat, and her sad attempt at selfdefense, manifest her as a complex character, if not in psychological, then in dramatic terms. Her role has even been described as "the meatiest, most tantalizing, most desirable role for a young female actress working in Canada today". ${ }^{1}$ While Sherrill Grace, one of Canada's leading experts on the dramatic discourse of the North, qualifies Heather's rage as being: “... not with the Indians but with her own romantic ignorance and Florence Nightingale arrogance, with the indifference of doctors and civil servants, and with the racist, imperialist assumptions that underlie interference in Native culture," (Grace, ed., 1999: 255), other critics have assumed a more critical standpoint toward the protagonist's position, and challenged its declared points of departure. One of them thus argues that:

In a broader sense, Heather Rose's story can be understood as a somewhat clichéd journey from ignorance to knowledge, a journey shaped by her gradual recognition of the destructive effects of racism and colonization on the lives of the people she has supposedly come to help. As is typical of this genre, the main character experiences a temporary loss of identity, and this allows her to question dominant societal attitudes that have constructed her point of view. Because the events of the narrative are retold from this newly politicized vantage point rather than dramatized directly on stage, the 
narrator serves as the voice of political resistance in the play. (Petropoulos 2003: 38)

The central metaphor of Heather's inner, as well as external strife, is the notion of "occupation," appearing for the first time in the play's title, and later in the dramatic climax of its action. On the first level, it refers, not surprisingly, to the protagonist's profession, which forms the foundation of her identity; toward the culmination of Heather's confessional monologue, however, its use pertains to another, and always inherently possible meaning, that of "the action of going into a place and taking control away from the people or government there" - this is a response of Heather's first and last patient on the reservation, Camilla Loon, who recourses to the "occupation" of the nursing station as a token of her passive resistance and expression of desperation caused by the fact that her prosthesis, ordered by Heather, never arrives. Her futile waiting and the quiet, solo act of occupation thus grow into a larger symbol of too many broken promises, arrogance, neglect, and failure of fruitful communication and cooperation between the centre and periphery, between the rich and the poor, the white people and the Native people, the South and the North - a symbol so potent that it impresses the exasperated Heather and drives her to one of her final exclamations, directed at her absent supervisor, for whom she has been waiting all along, as vainly as her patients have been waiting for any meaningful help on the reservation: "Fuck you, Miss Jackson. There's an old woman here with a wooden leg and I've got to make hot meals for her. There's an ancient Indian with a wooden leg occupying the nursing station and Nurse Rose is going to join her." (Grace, ed., 1999: 328).

In the final bitterly ironic quip by the lonely Heather, who now knows defeat and betrayal almost as well as her patients, we are told that Camilla's prosthesis arrived on the same plane that Heather left the reservation on; no "joining," let alone reconciliation, is happening, and the future looks gloomy for patient and nurse alike, thus sadly attesting to the fact that:

Sexism and racism, which have marred Canada's history in both the North and the South, continue to live on in the crafting and enactment of health policies. Sometimes it would seem that those who sculpt the policies or work within the health system are oblivious to the power structures within which they work. Yet women working within the health system, nurses in particular, are often caught in the structures and by the practices that result from their position in the health care hierarchy. (Anderson et al. 1997: 91-92)

Wendy Lill's play thus applies and echoes the discourse of health care, as personified by Heather Rose, to evidence not only the failure of the federal scheme of medical services and administration as inappropriate and culturally insensitive, but also to evidence its operation as one of the means of maintaining and structuring the persistent colonial legacy of which the character of the play, as well as the 
mainstream society, is both witness and victim. Tentative solutions, proposed, in this context, in both dramatic and medical literature, lie in proactive, equipollent communication between the mainstream and underprivileged communities, in assessing the needs of these communities from within, and in acknowledging their own competence in the solutions of problems, and cultural worth - simply, in letting the voices of minority communities be heard, and in listening to them with understanding and respect. Wendy Lill's play provides eloquent and persuasive dramatic evidence that the first steps have been taken.

Heather Rose's dramatic story thus represents a rare, unquestionably female version of the journey from the South to the North: not one of adventure and victorious conquest, not even a more edifying one of discovery - even the notion of the character's self-discovery is highly problematic - but, rather, one in which the North serves as the scene for publicly admitting certain constitutive realities of Canada's existence. The North, is, indeed, a place of terrifying ghosts, often one's own, projected upon the terrifyingly unfamiliar landscape, the conflict between which can result in truly rewarding dramatic catharsis:

North is perceived and dramatized as a place of purity and freedom, even when - as is so often the case - purity and freedom collapse into violence, greed, and madness. And it is represented, time and again, as both stunningly beautiful and staggeringly dangerous. It is a landscape of challenge to western concepts of masculinity, and, more broadly, to notions of civilization, truth, and to life itself. (Grace, ed., 1999: xix)

Minnie Aodla Freeman's earlier,1971 play Survival in the South offers a directionally opposed perspective on the Northern experience, both traditional and contemporary. Freeman, an Inuit woman from Cape Hope Island on the James Bay, left her native village at the age of twenty to work as a translator for the government in Ottawa, and was exposed to a most radical culture shock which led her to a systematic comparison of the implications, assumptions, habits and values of the two settings, the North vs. the South. Her play, by all evidence the first play ever written by an Inuit playwright, originally composed for the Dominion Drama Festival and later adapted as a radio play for the CBC, is the author's modest, yet authentic attempt to come to aesthetic, as well as emotional terms with the experience of her journey of (self)discovery, and to contribute to establishing an independent contemporary Inuit literary culture which would help defend the ethnic and cultural standing of the Northern people.

Freeman's humble, minimalistic play resembles Lill's The Occupation of Heather Rose in terms of the category of genre - both are female monodramas, in a sense extended dramatic monologues for one actress - as well as in the chosen basic narrative framework: both tell of one woman's experience of journey between the North and the South. Both protagonists also undergo their journeys in their professional capacities: Lill's Heather Rose as a nurse, Freeman's Minnie as a translator between English and Inuktitut for the federal government. Their 
relocations are thus motivated by the idea of providing valuable expert services, and by their means of facilitating communication and mutual understanding between the two locations and cultures. Both plays are also highly autobiographic; the honesty, openness, and personal tone of their dramatic confessions contribute to the authenticity and persuasiveness of the impression they create.

Freeman's play, however, appears at first sight - and judging by its title - to be a play about the South; yet, what matters in implication is not the realistic location but the perspective of experiencing. To paraphrase the title, the question is not so much survival where, but whose survival. Indeed, as Sherrill Grace claims, Canadian plays about the North are not necessarily simply set in the northern landscape but, rather, defined by it in implicit terms.

It is precisely this perspective of a "true Northerner" of herself, and of her Others, that qualifies Freeman's play as not a mere historical or anthropological document, but also as a potentially productive and convincing theatre material. The text of the play is extremely minimalistic in terms of the amount of words, expected length of performance, or intricacy of symbolism and imagery. It reflects the difficult and complex combination of the influence of the Inuit tradition of oral storytelling and the experience of many years of contact between the Inuit culture and the white civilization. The Inuit cultural roots of the play are not treated as existing in isolation, but in ontological and discursive interaction with the outside geographical context and its impact and power.

Northern constructions of North are both older and newer than southern ones, older insofar as they spring from the oral traditions and cultures of indigenous northern peoples and newer insofar as they are now being articulated in ways that make them more accessible south of sixty. Northerners represent their Norths in stories about a way of life, in myths about an ancestral homeland, or in images familiar in the South from sculpture, prints, and other arts. (Grace ed., 1999: xii)

Freeman's narrator observes reality that is, as such, familiar to the Southerner's eye; yet it experienced as ultimately different, and thus refreshingly defamiliarized. Many, seemingly childlike questions need to be asked, and a key to the "survival in the South" must be found:

How does one live in a totally different world and yet survive? My parents always told me, when not knowing what to do, and consequently afraid, I should always put on my best front - that is, smile, use my sense of humour and above all remain curious and alert so as to take advantage of opportunities to learn new things. (Gedalof, ed., 103)

During her emotionally taxing strife for survival Freeman's narrator (the author's unconcealed stage alter ego) encounters several personifications of her perspective's side of "The Other;" these are the White people she meets in the big city: 
the man who picks her up at the station upon her arrival, her roommate, her boss, a hairdresser, people rushing by on the busy streets. These people are well-meaning enough, but still come out as insensitive, contemptuous, irrational, and mostly incomprehensible. Moreover, all these encounters happen against the colourful backdrop of southern culture, the images of which strike Freeman as alien and frightening. Even an innocent, unassuming conversation of two people who have just met thus takes on profound cultural implications:

JANE: My name Jane... you... Eskimo?

MINNIE: Yes.

JANE: Really! Uh... where do Eskimos come from?

MINNIE: From the Arctic.

JANE: Arctic, eh - uh - I learned in Geography that Eskimos rub noses live in snow houses, and - eat raw meat - Did you do all that?

NARRATOR: This girl has no self-control.

MINNIE: Yes!

JANE: Really?

(Pause)

Are you shy? You don't say much. I guess you are shy.

NARRATOR: True, no sense of self-control. (Gedalof, ed., 105-06)

What the readers and audiences experience in Freeman's play is a reversal of the process described by Alan Filewod as "averting the colonizing gaze;" in his "Notes on Watching [Canadian] Native Theater" Filewod admits:

I can't write about native theater. All I can write about is my response to it. When I watch native theater I see my own gaze returned; my watching is an appropriation, even when it is invited. As the colonizer I am the invisible presence in these plays. (Brask, ed., 17)

It is a reversal in the sense that here the mainstream audiences are not watching a specimen of a foreign, perhaps exotic culture, but instead are looking into a mirror in which they ultimately recognize their own image, including their limitations of judgment about a component of their national identity which has been so gloriously appropriated, and at the same time remained largely ignored and misunderstood. And what has remained misunderstood most is that the North is not merely an immense landscape of extremity, but that it is a home of genuine, distinctive cultures existing there in their own right.

Even though Freeman's play may appear as too simple, if not simplistic, to some sophisticated Western audiences, it displays an engaging stage potential, discernible in the stage notes for the text. They provide indications as to the movement of the supporting actors which illustrates the estranging atmosphere of the big city and the chaos that impedes comprehension and communication - both interpersonal and intercultural. They include indications such as: "Train 
enters, brakes, changes into people - All stop - continue - All start" (Gedalof, ed., 101), sometimes employ colour symbolism: "They walk to the street crossing, then stop is the cue for the red traffic lights, enter traffic, rush by and then exit. Exit is cue for green traffic lights, Minnie follows woman" (Gedalof, ed., 108), or describe the use of gesture and body language: "He motions to secretary, she follows chief, office stops to look at Minnie, then all continue - slow fade and then back on lunch bell - all rush for elevator to descend" (Gedalof, ed., 109-110). This conception of movement is derived from the traditional understanding of the performative capacity of the human body in Inuit culture, the primary function of which is demonstrative and educative. As such, its cultural peculiarity may not be as insurmountable as it seems. During her work in the Inuit community of Pangnirtung Cindy Cowan, playwright, social worker and educator, noticed:

... similarities to epic theatre, especially to the technique formulated by Brecht called the gestus - in essence a series of gestures and attitudes that would establish, even without dialogue, the characters' social relationships. Inuit theatre shares with epic theatre this non-verbal sensibility, in addition to an emphasis on humour and storytelling instead of psychology. (Cowan 1992: 27-28)

The technique resembling that of epic theatre is also discernible in the general structure of Freeman's play: the leading voice is split between the "narrator," who stands in front of the audiences and delivers the outline of the story in the capacity of a traditional storyteller, and the character identified as "Minnie," who relives and "acts out" her past experience. The two share their identity, which is the author's, and the transfers between them are very smooth and fluid (at the same time echoing even the traditional Inuit shamanistic belief in transformation). Cindy Cowan observed:

As in Brechtian theatre, Inuit actors do not necessarily become possessed by their characters; indeed, many actors will use their own names on stage [...] and deliver their line centre stage into a microphone [...] acting is rooted in an acute awareness of one's true identity at all times. In a sense, both actors and audience develop a critical attitude, instead of losing themselves in a hypnotic identification. (Cowan 1992: 27)

At the same time, however, Cowan rightly points out that:

What is important is not that Inuit theatre is like Brechtian theatre, but that the Inuit approach to theatre is something more than simply "entertainment." With this as an objective they have arrived at techniques which are identified with Brecht, but which arise out of the common and collective experiences of the company members. (Cowan 1992: 28) 
Another aspect that Lill's and Freeman's plays have in common is that they both end in a tone of resignation, anxiety, embittered irony, and intense introspection. At the end of her story Minnie ("Miss Aodala," as her boss calls her) is appointed as a consultant for a new government program titled: "How to survive in the North." The title of the program, announced half-jokingly at a meeting, paraphrases the title of the play and Minnie's so-far held perspective of the notion of survival. Her quiet, tired last words, addressed to no one in particular (or to anyone who might be willing to listen and take the message), represent a verbal rendition of "averting the colonizing gaze" toward the need of introspection, toward itself:

They ask me how to survive, they don't tell me how to survive in the South... I am not worthy for these people... I am nothing to them; it does not matter whether I survive or not in their country; I am nothing to them, therefore, I have to help them in how to survive in my land - ugh, it's hot in this place...

Fade to end. (Gedalof, ed., 112)

The pessimistic conclusions of Lill's and Freeman's plays are, hopefully, not to be taken in absolute terms; rather, they are to provoke pertinent, if unpleasant, questions about the very foundations of Canadian national and cultural identity and its relationship to the North, for which performative art has proven to provide an effective, dynamic, and meaningful platform. As Sherrill Grace puts it:

Staging the North [...] is not a matter of putting elaborate realist sets of rocks, snow, pine trees and igloos on the boards but of exploring the multifaceted capacity of the North to fascinate, haunt, repel, lure, and trouble the southern Canadian imagination. (Grace 2001: 154)

Both plays thus dramatize the experience of the journey to/from the North, undertaken by two women representing different, yet not mutually eliminating cultural positions. They provide plastic images of the Northern environment, culture and landscape, but not as mere factual information, but as emotionally and aesthetically engaged and sensitive testimony of what is not only a real, but strategically indispensable composite of the Canadian reality.

\section{Notes}

http://compthis.blogspot.com/2007/08/last-play-I-shall-write-about-today.html, accessed August 20, 2016.

http://www.macmillandictionary.com/dictionary/british/occupation. Accessed August 20, 2016. 


\section{References}

Anderson, Joan, Sherrill Grace, Gabriele Helms, Matt James and Patricia Rodney (1997) 'Women speaking: Heather Rose and the culture of health care'. In: McLarnon, Shauna and Douglas Nord (eds.) Northern Parallels: Fourth Circumpolar Universities Cooperation Conference Proceedings. Prince George, BC: University of Northern British Columbia Press, 84-101.

Barbee, Evelyn L (1993) 'Racism in U.S. nursing'. Medical Anthropology Quarterly 7(4), 346-362.

Carnegie, Mary E.L. and Estelle M.R. Osborne (1985) 'Integration in professional nursing'. In: Hine, Darlene Clark (ed.) Black Women in the Nursing Profession: A Documentary History. New York: Garland Publishing, 145-148.

Cowan, Cindy (1992) 'The trap of cultural specificity: Seeking intercultural solidarity'. Canadian Theatre Review 73, 24-28.

Filewod, Alan (1992) 'Averting the colonizing gaze: Notes on watching native theater'. In: Brask, Per (ed.) Aboriginal Voices: Amerindian, Inuit and Sami Theater. Baltimore: Johns Hopkins University Press, $17-28$.

Freeman, Minnie Aodla (1982) Survival in the South. In: Gedalof Robin (ed.) Paper Stays Put. A Collection of Inuit Writing. Washington: University of Washington Press, 101-112.

Gedalof, Robin (ed.) (1982) Paper Stays Put. A Collection of Inuit Writing. Washington: University of Washington Press.

Grace, Sherrill, Eve d'Aeth and Lisa Chalykoff (eds.) (1999) Staging the North. Canadian Plays. Toronto: Playwrights Canada Press.

Grace, Sherrill (2001) Canada and the Idea of North. Montreal and Kingston: McGill-Queen's University Press.

Lill, Wendy (1999) The Occupation of Heather Rose. In: Grace, Sherrill, Eve d'Aeth and Lisa Chalykoff, (eds.) Staging the North. Twelve Canadian Plays. Toronto: Playwrights Canada Press, 298-330.

Petropoulos, Jacqueline (2003) 'Language and racism: Wendy Lill's The Occupation of Heather Rose'. Canadian Theatre Review 114, 38-41.

Sartorio, Natalia de Araujo and Elma Lourdes Campos Pavone Zoboli (2010) 'Images of a "good nurse" presented by teaching staff". Nursing Ethics 17(6), 687-694.

Wyonarski, Blair (2011) 'The occupation of Heather Rose an emotional roller coaster with a generous dose of reality'. http://www.thesheaf.com/2011/02/10/the-occupation-of-heather-rose-anemotional-roller-coaster-with-a-generous-dose-of-reality/, accessed on August 14 $4^{\text {th }}, 2016$.

Klára Kolinská teaches at the Department of Anglophone Studies of Metropolitan University, Prague, Czech Republic, and at the Department of Anglophone Literatures and Cultures of Charles University, Prague. Her main areas of teaching and research include early and contemporary Canadian fiction, theatre and drama, multiculturalism, and Aboriginal literature and theatre. She has published mainly on Canadian Aboriginal literature and theatre, Canadian prose fiction, contemporary drama and theatre, and theory and practice of narrative and storytelling.

Address: Klára Kolinská, M.A., PhD., Katedra anglofonních studií, Metropolitní univerzita Praha, o.p.s., Učňovská 100/1, 19000 Praha 9, Czech Republic. [email: klara.kolinska@mup.cz] 